\title{
Industrial Accident
}

National Cancer Institute

\section{Source}

National Cancer Institute. Industrial Accident. NCI Thesaurus. Code C34343.

An accident taking place on the site of a commercial enterprise. 